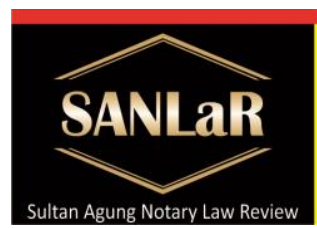

\title{
Result of Law on Construction of Flats which are Granted Ownership Rights Over the Building Use Rights
}

\author{
Khoeron $\left.{ }^{*}\right)$ \\ *) Students of Master of Notary Law, Faculty of Law, Universitas Islam Sultan \\ Agung (UNISSULA) Semarang, E-mail: choeron598@gmail.com
}

\begin{abstract}
The study, entitled "The Legal Consequences for the Construction of Flats Which Are Given Ownership Status over Building Use Rights in the City of Semarang" in order to find out and analyze legal protection for apartment owners with ownership rights over building use rights and legal consequences of building flats with ownership rights above the right to build. This study uses an empirical juridical approach, which is a legal research conducted by examining and analyzing existing facts in line with observations in the field. Legal protection of ownershipownership rights to flats above the right to use the building, of course based on evidence of legal certainty obtained by the owner of the apartment unit in the form of a certificate of ownership of the apartment unit. Ownership of one flat is certainly owned by each individual who owns the flat with horizontal and vertical separation principles. The regulation regarding the right to build itself explains that the legal consequence of the expiration of the term of the right to build will result in land falling to the state so that each resident of the apartment with the joint management of the apartment must still pay attention to the period of time for the unit belonging to the apartment. The legal consequence of the construction of a flat above the right to build is that based on the principle of horizontal separation so that there is proof of ownership of the apartment which is explained in the certificate that the ownership rights to the apartment unit are not eliminated provides a certainty of ownership of the apartment. The status of the apartment on the right to build will certainly result in each resident of the apartment paying the cost of extension of the building use right because in this case if the right to use the building ends it will have an impact on the status of the land that is jointly owned in the form of public facilities around the house stacking.
\end{abstract}

Keywords: Legal Certainty; Property Rights; Flats.

\section{Introduction}

Population growth and economic growth will have an impact on development so that there must be synergy with the current population growth. For this reason, the need for land is not only used for agricultural land but can also be used to build habitable residential buildings. Housing development carried out by the government and developers is an effort to meet basic human needs. One of the goals of the construction of flats is of course expected to reduce land use and 
make space more spacious is one of the alternatives. ${ }^{1}$ The construction of flats is adjusted to the concept of settlement and housing development which must meet and have the eligibility criteria to be made into a healthy, safe and harmonious residence. ${ }^{2}$ Article 24 of Act No. 20 of 2011 concerning Flats explains that the construction of flats must meet technical and administrative requirements. This effort is of course aimed at realizing a dwelling that has high standardization, so as to make the occupants comfortable to live in the flat.

With the increase in economic growth that occurs as a result of the pace of development, there is a demand for an increase in the need for land both for industrial, service and residential purposes such as housing and offices. The construction of flats, of course, can also result in the opening of urban space more relieved and in this case also helps to rejuvenate the city, so that day by day the slum area decreases and then becomes a neat, clean and orderly area. The need for shelter, of course, makes basic human needs that must be fulfilled by the community as a place of shelter after daily activities. Residential that is suitable for habitation on land with strong legality will certainly provide comfort for the people who occupy the dwelling. However, the need for land is increasing due to development activities and increasing population growth which is not matched by a limited land supply.

The construction of flats is a very good way to solve the problem of the needs of housing and settlements in densely populated locations, especially in urban areas where the population is always increasing, while land is getting more and more limited. According to Article 45 of the Flat Law, control of flat units can be carried out in various ways. For public flats and commercial flats under control, it can be owned or rented. Control over apartments in these ways can be carried out by means of a written agreement made in the presence of an authorized official. The written agreement must be registered at the association of owners and residents of a condominium (PPPSRS), which is a legal entity whose members are the owners or residents of apartment units. An apartment in which there is a modern shopping center building can be called an apartment if in a shopping center there is ownership of each unit in the name of an individual or legal entity whose use is for commercial and non-residential use for shopping centers only

The density of the population in the city of Semarang will have an effect on the residence of the people of Semarang City, which is actually the construction of flats in the city of Semarang to meet the needs of proper housing for the people of Semarang City, especially those who have low income which ensures legal certainty in its use and to increase its usability and efficiency. the results of land

\footnotetext{
${ }^{1}$ Suriansyah Murhaini. (2015). Hukum Rumah Susun. Surabaya: Laksbang Grafika p. 1.

${ }^{2}$ Andi Hamzah. (2011). Dasar-Dasar Hukum Hukum Perumahan. Jakarta: Penerbit Rineka Cipta. p. 3.
} 
use in the city of Semarang while still paying attention to the preservation of natural resources and creating a complete, official, and balanced residential environment. The advantage of the construction of flats is that the land needed to build a flat does not need to have a large area of land and can be maximally utilized in accordance with the spatial layout of the city of Semarang so that urban development can be realized.

\section{Research Method}

The approach method in this research is empirical juridical research method. Empirical juridical research is legal research regarding the enactment or implementation of normative legal provisions in action at any particular legal event that occurs in society, namely studying and researching Law in Action. ${ }^{3}$ The juridical approach is an approach that emphasizes the aspects of legal norms that exist in statutory regulations and other legal provisions. The approach in research is to provide a field analysis of the implementation of the construction of flats which will have legal consequences in granting ownership rights over building use rights in the city of Semarang.

\section{Results and Discussion}

The construction of flats which aims to provide proper housing certainly provides a guarantee of legal certainty, so it requires a legal rule that is implemented consistently on its application. The form of land registration related to the construction of flats is very much needed, especially the guarantee of legal certainty given as the owner of the apartment. The form of state protection for the entire community for the fulfillment of welfare is stated in Article $28 \mathrm{H}$ of the 1945 Constitution of the Republic of Indonesia, which states that everyone has the right to live in physical and mental prosperity, to live in, and to have a good and healthy living environment and the right to obtain health services and everyone has the right to have private property rights and ownership rights may not be taken arbitrarily by anyone.

To provide legal protection as illustrated by the functioning of the legal function to realize the objectives of the law itself which consists of justice, certainty and benefit of the law. Legal protection is a protection provided to legal subjects in accordance with the rule of law, both in a preventive nature (prevention) or in a repressive form (coercion), both written and unwritten in the framework of enforcing legal regulations. One of the efforts given by a government to the community is the construction of flats in the city of Semarang which has several houses with apartment buildings, this is part of fulfilling the rights of citizens, especially those in the low-income category, as the purpose of the construction of these flats is of course to provide space for people with middle to lower

${ }^{3}$ Abdulkadir Muhammad. (2004). Hukum dan Penelitian Hukum. Bandung: Citra Aditya Bakti. p. 134 
income. The construction of these flats will certainly increase the efficiency of land and space use in the city of Semarang. The existence of flats will certainly provide a value for the quality of life of the community, especially those in the middle to lower income category. Part of the construction of flats of course also relates to the improvement of facilities and infrastructure provided to provide fulfillment of the rights given to the community. The construction of flats is part of the needs of the community which makes flats an alternative part to provide adequate housing and reduce uninhabitable settlements.

Every ownership of an apartment must, of course, be proven by ownership of the right to have a flat unit in the form of a certificate of ownership. Ownership rights over flat units as part of an effort to provide legal protection for ownership of flat units. Ownership rights over apartment units are something that is "Not a right to land, but is related to land." Ownership rights over apartment units, which are individual and separate, which also includes joint ownership rights over what is called "common share", "common land", and "common property". All of them are one thing that is inseparable from the ownership of a flat unit. The parts which can be owned and used separately are called Flat Units. The apartment unit must have a means of connecting to a public road, ${ }^{4}$

Efforts to protect the law of apartment ownership are evidence of legal certainty obtained by the owner of the apartment unit. This proof of ownership with a certificate is a strong proof of ownership of land rights. To obtain a land certificate, it is certain that the land rights must be registered at the Land Registration Office. ${ }^{5}$ There are several evidentiary characteristics of a certificate as proof of ownership as stated in Article 32 of Government Regulation No. 24 of 1977 concerning Land Registration, namely: ${ }^{6}$ First, a certificate is a certificate of proof of rights which is valid as a strong means of evidence regarding the physical data and juridical data contained therein, as long as the physical data and juridical data are in accordance with the data contained in the measuring letter and the land book concerned. Second, in the event that a land parcel has been legally issued a certificate in the name of the person or legal entity that acquired the land in good faith and actually controls it.

Legal Consequences of Construction of Flats with Freehold Status Above Building Use Rights

The construction of flats in an effort to increase the efficiency and yield of land use for housing development, of course, aims to improve the quality of the residential environment, especially in densely populated areas, one of which is in the city of Semarang, but only a limited area of land is available so that the

\footnotetext{
${ }^{4}$ Boedi Harsono, Op Cit, p. 245

${ }^{5}$ J.Andy Hartanto. (2009). Problematika Hukum Jual Beli Tanah Belum Bersertifikat. Yogyakarta: Laksbang Mediatama. p. 16.

${ }^{6}$ Ibid, p. 22
} 
construction of flats is a solution for address a more regular layout. Proof of ownership of the apartment unit will be issued SHMSRS which contains the Proposional Comparison Value (hereinafter referred to as NPP), namely the numbers that show the comparison between the synergy against the rights to common shares, common objects, and common land. The NPP is calculated when the construction operator or developer has finished building by calculating the total cost of the construction.

Ownership right of flat land is part of the overall joint ownership rights of the owner of the apartment unit whose one unit cannot be separated. Ownership rights over apartment buildings are always connected to the individual ownership and joint ownership system known as the condominium system. The existence of a condominium system is a system that regulates joint ownership of a certain legal object, which is generally in the form of immovable objects, namely land and buildings standing on it. The implementation of a condominium system that combines elements of individual ownership and elements of joint ownership.

Status of ownership rights over building use rights will certainly result in the tenure of ownership of the apartment. The right to build that is not extended when the period ends, the land that has the status of building use rights will become state land. In the explanation of Article 17 Letter $c$ that there is a legal consequence in the construction of flats with the status of ownership rights over building use rights as can be established on land with right to building and right to use which is above management rights so that the importance of a certificate of right to a flat unit on the basis of rights contained in the Law on Flats to guarantee legal certainty in its implementation.

Evidence of the ownership of the apartment that has been valid so far is the Right to Own to the Apartment Unit which unites the apartment unit (Sarusun) with the land, namely the flats built on land with Ownership, Building Use Rights and Right to Use over land with proof of Certificate of Rights Ownership of Apartment Unit (SHM Sarusun). Legal certainty regarding the legal position of the objects attached to the land is very important because this has a broad influence on all legal relationships relating to land and the objects attached to it. ${ }^{7}$ To be able to register a certificate of ownership rights over a flat unit, there must first be a certificate of title to the land in the form of ownership rights, building use rights as well as usage rights and management rights. To be able to register a certificate of ownership rights over a flat unit, there must first be a certificate of title to the land in the form of ownership rights, building use rights as well as usage rights and management rights. In Article 39 paragraph (1) Government

\footnotetext{
7 Djuhaendah Hasan. (1996). Lembaga Jaminan Kebendaan Bagi Tanah Dan Benda Lain Yang Melekat Pada Tanah Dalam Konsepsi Penerapan Asas Pemisahan Horisontal. Bandung: PT. Citra Aditya Bakti. p. 65
} 
Regulation Number 4 of 1988 concerning Flats, it is expressly stated that the organizer of the construction is obliged to separate the flats from the apartment units including common parts, common objects and land together with a clear description in the form of pictures, descriptions, and the boundaries in the vertical and horizontal direction as referred to in Article 31, with the necessary adjustments according to the reality which is carried out by drawing up a deed of separation. Whereas in paragraphs 3 and 4 it is stated that the deed of separation as referred to in paragraph (1) is legalized by the Regional Government attached with a picture, description and boundaries as referred to in Article 30 and Article 31. And in paragraph (4) it is stated that the deed of separation as referred to in paragraph (3) must be registered by the development organizer at the Regency or Municipal Agrarian Office by attaching a certificate of land rights, habitable permits, along with other documents.

4. Closing

\subsection{Conclusion}

Based on the results of the research and discussion in the previous chapter, it can be concluded that:

1. Legal protection for apartment owners with the status of ownership rights above the Building Use Rights is the granting of a Certificate of Ownership on the Apartment Unit as proof of ownership will provide legal protection for the apartment owner. Each apartment ownership certainly has authentic evidence that is owned by every resident of the apartment who has gone through the land registration stage at the land office of each district / city. The legal protection provided by the state not only provides a decent life but also pays attention to things that occur in the future, one of which is if there is a dispute over ownership until the status of the right to use the building will end. The existence of proof of ownership of a flat certificate will provide absolute legal certainty as from the purpose of the law itself is to provide certainty, benefit and justice. The operation of law in society will certainly be seen from the effectiveness of a rule that is able to provide overall justice for people who do not have absolute power before the law.

2. The legal consequence of the construction of flats with the status of ownership rights over building use rights is when the term of the building use rights expires, so that the residents of the apartment must also know the period of expiry of the building use rights even though in this case there is a principle of horizontal and vertical separation of ownership flats. If the right to use the building ends, the land will become state land so that the party that builds the apartment must notify the time period earlier and notify the apartment management to immediately extend the period of 1 year before the term of the building use right expires. 


\subsection{Suggestion}

Based on the above conclusions and the descriptions that have been explained, there are several suggestions, namely:

1. For the residents of the apartment, they must also pay attention to the status of the apartment they have, because to find out earlier about the status of the apartment, they are always more thorough and careful in matters relating to the status of property rights that are above the right to use the building.

2. The form of legal protection provided by the state by providing apartment certificates must be accompanied by periodic socialization in notifications related to property rights, rights to use buildings, rights to use, and other rights.

\section{References}

Journals:

[1] Ina Budhiarti Supyan. Februari 2016. "Perlindungan Hukum Bagi Penghuni Satuan Rumah Susun Dibidang Pengelolaan Rumah Susun Di Bandung Dihubungkan Dengan Undang-Undang Nomor 20 Tahun 2011 Tentang Rumah Susun". Jurnal Wawasan Hukum. Vol.34. No.1

[2] Paulus Hadisoeprapto, dkk, Pedoman Penulisan Usulan Penelitian dan Tesis, Semarang: UNDIP, 2009

[3] Boedi Harsono, Berbagai Masalah Hukum Bersangkutan Dengan Rumah Susun dan Pemilikan Satuan Rumah Susun, Jakarta: Majalah Hukum dan Pembangunan, 1986.

[4] R. Rizka Mardia, 2010, Implemantasi UU Nomor 16 Tahun 1985 Tentang Rumah Susun (Study Kasus Rumah Susun Kaligawe Semarang), Skripsi: Faculty of Law, Universitas Diponegoro.

Books:

[1] Abdulkadir Muhammad. (2004). Hukum dan Penelitian Hukum. Bandung: Citra Aditya Bakti

[2] Andi Hamzah. (2011). Dasar-Dasar Hukum Hukum Perumahan. Jakarta: Penerbit Rineka Cipta

[3] Adrian Sutedi. (2010). Hukum Rumah Susun dan Apartemen. Jakarta: Sinar Grafika

[4] A.Ridwan Halim. (1989). Hak Milik Kondominium Dan Rumah Susun. Jakarta: Puncak Karma 
[5] Boedi Harsono. (2008). Hukum Agraria Indonesia, Sejarah Pembentukan Undang-Undang Pokok Agraria Isi Dan Pelaksanaannya. Jakarta: Djambatan

[6] Bambang Sunggono. (2006). Metode Penelitian Hukum. Jakarta : PT Raja Grafindo Persada

[7] Bambang Sunggono. (1997). Metodologi Penelitian Hukum. Jakarta: Rajawali Press

[8] Djuhaendah Hasan. (1996). Lembaga Jaminan Kebendaan Bagi Tanah Dan Benda Lain Yang Melekat Pada Tanah Dalam Konsepsi Penerapan Asas Pemisahan Horisontal. Bandung: PT. Citra Aditya Bakti

[9] Imam Koeswahyono. (2004). Hukum Rumah Susun: Suatu Bekal Pengantar Pemahaman. Malang: Bayumedia

[10] J.Andy Hartanto. (2009). Problematika Hukum Jual Beli Tanah Belum Bersertifikat. Yogyakarta: Laksbang Mediatama

[11] Lexy Moleong, Metode Penelitian Kualitatif, Bandung : Remaja Rosdakarya, 2004.

[12] Ronny Hanitijo Soemitro. (1990). Metodologi Penelitian Hukum dan Jurimetri. Jakarta: Ghalia Indonesia

[13] Rinto Manulang. (2011). Segala Hlm Tentang Tanah Rumah dan Perizinannya. Jakarta: Buku Pintar

[14] Soerjono Soekanto and Sri Mamudji. (1983). Penelitian Hukum Normatif. Jakarta: Rajawali

[15] Suriansyah Murhaini. (2015). Hukum Rumah Susun. Surabaya: Laksbang Grafika

[16] Suhartini Arikunto. (2001). Prosedur Penelitian dan Survey. Yogyakarta: Aneka Cipta

[17] Soejono Soekanto and Sri Mamudji. (1995). Penelitian Hukum Normatif. Jakarta: Raja Grafindo Persada

[18] Urip Santoso. (2010). Hukum Agraria \& hak-hak Atas Tanah. Jakarta: Kencana Prenada Media Group

[19] Urip Santoso. (2011). Pendaftaran Tanah dan Peralihan Hak Atas Tanah. Jakarta: Kencana

[20] Zainuddin Ali. (2010). Metode Penelitian Hukum. Jakarta: Sunar Grafika

Regulations:

[1] Act No. 5 of 1960 concerning Agrarian Principles 
[2] Law of the Republic of Indonesia Number 20 of 2011 concerning Flats

[3] Government Regulation Number 24 of 1997 concerning Land Registration

Internet:

RidwanHalim,S.H, in http://wrumaisah.wordpress.com/2011/09/23/pend aftaran-hak-milik-atas- satuan-rumah-susun-di-dki-jakarta/, accessed on April 3, 2020. 